\title{
Characteristics and causes of forest and land fires in Kapuas District, Central Kalimantan Province, Indonesia
}

\author{
ACHMAD SIDDIK THOHA ${ }^{1, \boldsymbol{v}}$, BAMBANG HERO SAHARJO ${ }^{2}$, RIZALDI BOER ${ }^{3}$, MUHAMMAD ARDIANSYAH ${ }^{4}$ \\ ${ }^{1}$ Faculty of Forestry, Universitas Sumatera Utara. Jl. Tridarma Ujung No. 1, Medan 20155, North Sumatra, Indonesia. Tel./fax.: +62-61-8220605, \\ "email.siddikthoha@gmail.com. \\ ${ }^{2}$ Department of Silviculture, Faculty of Forestry, Institut Pertanian Bogor. Jl. Raya Dramaga, Bogor 16680, West Java, Indonesia. \\ ${ }^{3}$ Department of Geophysics and Meteorology, Faculty of Mathematics and Natural Sciences, Institut Pertanian Bogor. J1. Raya Dramaga, Bogor 16680, \\ West Java, Indonesia \\ ${ }^{4}$ Department of Soil Science and Land Resource, Faculty of Agriculture, Institut Pertanian Bogor. Jl. Raya Dramaga, Bogor 16680, West Java, Indonesia
}

Manuscript received: 24 September 2018. Revision accepted: 3 Desember 2018.

\begin{abstract}
Thoha AS, Saharjo BH, Boer R, Ardiansyah M. 2019. Characteristics and causes of forest and land fires in Kapuas District, Central Kalimantan Province, Indonesia. Biodiversitas 20: 110-117. Forest and land fire occurs almost every year in Indonesia. Its impact is very harmful for human and environment. Developing a program in fire management requires identification of forest and land fire characteristics and its causes. The aim of this research was to evaluate the characteristics and causes of forest and land fire in Kapuas District Central Kalimantan Province. Spatial analysis of hotspots with rainfall was used to determine temporal distribution of fire. Spatial distribution between hotspot and causative factors was determined to identify spatial characteristics of fires. Increasing number of hotspots occurs when monthly rainfall decreases. Most high fire activities are located in peatland, swamp shrubs, close to road, close to river and far away from villages. Fire causes from human activities mostly originated from swamp shrub burning and land clearing for farming. Hotspot density has various relationship with peat depth, land cover, accessibility, and human activities.
\end{abstract}

Keywords: Causes of fire, forest fire, land fire, hotspot

\section{INTRODUCTION}

Forest and land fires and the impacts have spread to various areas including Kapuas District in Central Kalimantan Province. In Kapuas District, there are hundreds of thousands of hectares of peatland located in the former area of Pengembangan Lahan Gambut (PLG)/Peatland Development Million Hectares which was started in 1995. The PLG project cleared a very wide peatland including swamp forest with thick peat. The project also undertook the construction of thousands of kilometers of canals impacting the draining of peat ecosystems due to drainage processes that reduce peat volume above groundwater level. The draining of the peat ecosystem makes areas particularly vulnerable to forest and land fires, resulting in massive carbon emission (Hooijer et al. 2008). According to Cochrane (2003), carbon emission from burned peat fires is enormous. Fire from tropical peatland produces carbon dioxide emissions 4-40 times larger than other tropical ecosystems.

Based on the result of fire occurrence identification, Kapuas District is one of the observed areas where forest and land fires often occur. Research of Jaya et al. (2008) mentioned that Kapuas district is an area that has an extreme risk class in Central Kalimantan because most of the ex-PLG area of a million hectares is located in Kapuas District. WIIP (2007) and Ministry of Forestry (2011a) reported that fires in 2002, 2007 and 2011 in the Ex-PLG area disrupted community activities and exacerbated the damage to peatland ecosystems.
Causing factors of fires according to some research results are related to climate and human activities. Research of Ceccato et al. (2010) found that there was a close relationship between rainfall anomalies and fire hotspots in Central Kalimantan. The occurrence of rainfall anomalies during dry season in June-October is a critical time of fire activity. According to Jaya et al. (2008), human factor contributes $52 \%$ to fire risk and land cover $48 \%$. Thoha et al. (2017) also found that land cover had high contribution to fire risk model in Kapuas District, namely $48 \%$.

Forest and land fire management efforts are aimed to reduce the occurrence of fires that may affect life and livelihoods. Fire characteristics such as frequency of occurrence, weather factors and spread of fire indications by biophysical factors and human activities are needed as inputs for the development of early warning systems of forest and land fires in a particular region. In addition, the causes of forest and land fires related to human activities need to be properly identified so that their management strategies can be determined appropriately and effectively. Therefore, the characteristics and causes of fires need to be determined appropriately in each region.

The objectives of this research were to evaluate the characteristics and causes of forest and land fire in Kapuas District Central Kalimantan Province The results of this study are expected to be used for evaluation of the characteristics of forest and land fires occurring in Kapuas District, Central Kalimantan Province, Indonesia based on time, location distribution and cause of fire. 


\section{MATERIALS AND METHODS}

\section{Study area}

The research was conducted in Kapuas District, Central Kalimantan Province, Indonesia (Figure 1) in April 2012September 2013. Field data collection and interviews were conducted in 20 villages in 9 sub-districts in Kapuas District. The nine sub-districts were Mantangai, Dadahup, Basarang, East Kapuas, Kapuas Murung, West Kapuas, Selat, Kapuas Kuala, Central Kapuas, Lapak Taliwang and Timpah.

\section{Materials}

Hotspot data from Terra/Aqua Satellite with MODIS (Moderate-resolution Imaging Spectroradiometer) sensor in 2002-2012 was obtained from Fire Information for Resource Management System (FIRMS 2012) which can be accessed for free at link https://firms.modaps.eosdis.nasa.gov/download. Maps of district and sub-district administrative boundaries were obtained from the Regional Development Planning Board (Bappeda 2012) of Kapuas District. Land cover map, river network map, road network map, village center map and peatland map were collected from the Ministry of Forestry (2011b) that were used for the analysis of spatial and temporal distribution of fire activity. Hotspots were also used as a basis for determining the location of ground check. Monthly rainfall data were obtained from the rain station from Agriculture and Food Security Office of
Kapuas District (2012) to analyze the relationship between hotspots and rainfall. The tools that were used in this study were personal computer, GIS software, spreadsheet tool, and Global Positioning System (GPS) navigation version.

\section{Procedures}

The data of rainfall and hotspot were cross-tabulated to get relationship graph between them. The hotspot data were converted to hotspot density representing the fire activities in the field. Then, hotspot was overlaid by spatial analysis tool with various maps, i.e., maps of land cover, distance to river and canal, distance to road, distance to village center, land type, and peat depth.

The locations of the ground-check were determined through visual analysis of hotspot density and visual analysis of Landsat ETM 7+ imagery and Landsat TM Imagery 2001-2010 as well as information from the Kapuas and Plantation Forestry Office of Kapuas District (2013) and Manggala Agni Regional Operation II Kapuas (Ministry of Forestry 2011a). Ground-check and in-depth interviews with communities were conducted to confirm land cover type, land based community activities and causes of fire at fire indicated sites based on hotspot distribution and technical agency information. The data of ground-check that were collected consisted of hotspot coordinates (GPS point), land cover, fire incident information from year to year, causes of fire and community activities.

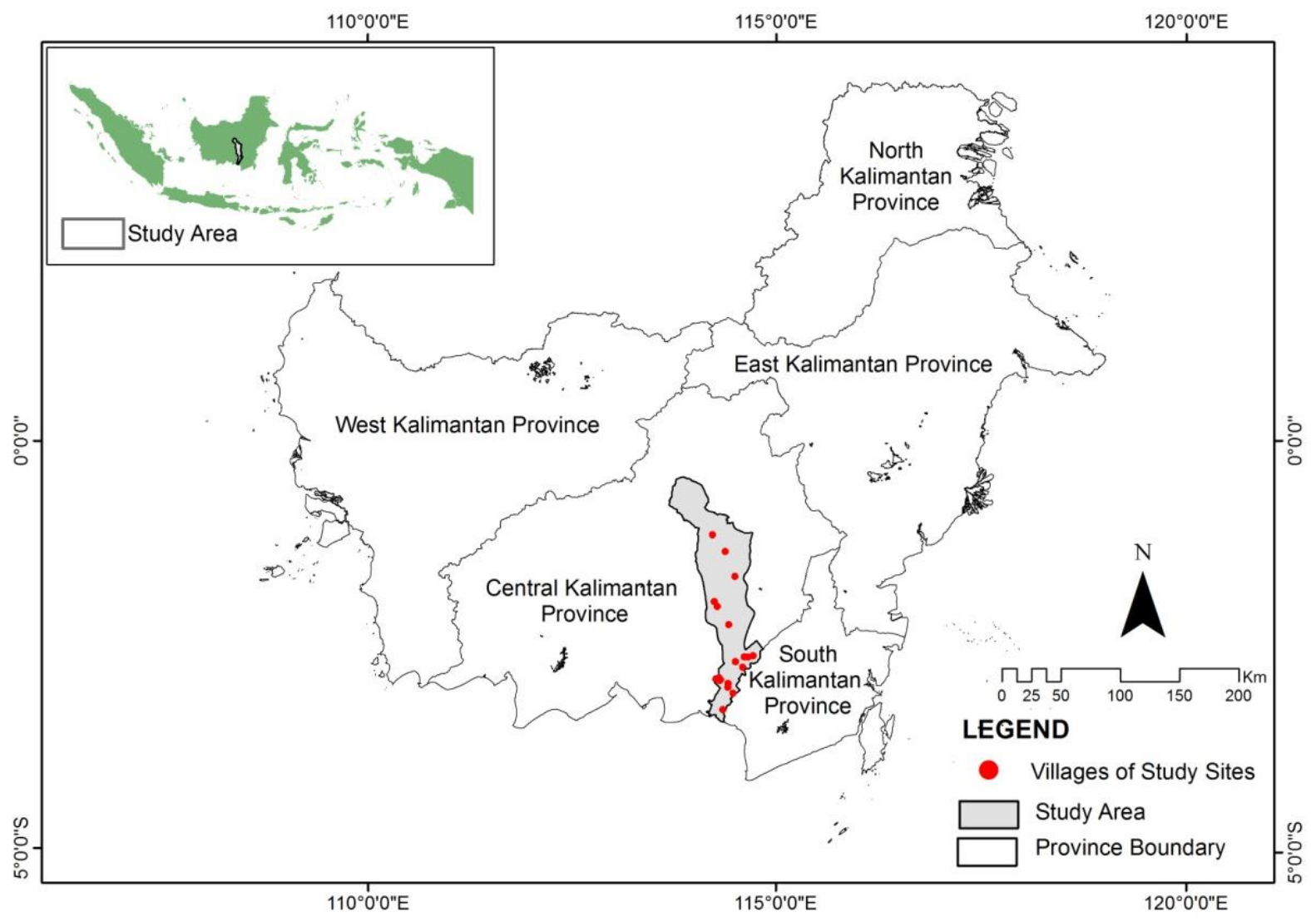

Figure 1. Study area in Kapuas District, Central Kalimantan Province, Indonesia 


\section{Data analyses}

Determination of relationship between hotspot and rainfall was done by field rainfall data analysis and number of annual hotspots and monthly hotspots using a spreadsheet software. Hotspot density was used for determining the relationship of fire occurrence and the driving factors of fire. This process was done with Spatial Join and Kernell Density using ArcGIS software. Hotspot density represents fire indication or fire activity in the field. Spatial-temporal analysis was done descriptively to see the indications of forest and land fire from time to time and its distribution based on various factors. The result of temporal analysis was compared with the history of forest and land fires originating from the results of community interviews. The determination of causes of fires in the field was done through field checks and interviews. Analysis of fire location distribution indication was based on hotspot distribution overlaid with maps of distance from the river, distance from the road, distance from village center, land cover and thickness of peat. Causes of forest and land fire were described descriptively to explain various activities that cause fire.

\section{RESULTS AND DISCUSSION}

\section{Hotspot temporal distribution, rainfall and its relation to community activities}

During 11 years as shown in Figure 2, the highest hotspot was seen in 2002, repeated later in 2006 and in 2009. In condition where rainfall decreased hotspot tended to increase. In contrast, the number of hotspots decreased as the number of rainfall increased in 2007, 2008 and 2010.
Based on community information in 11 sub-districts in Kapuas District as presented in Table 2, most fires were caused by wild flames from scrub or abandoned land and burned forest for plantation. Many shrublands were found in ex-PLG areas and areas with unclear land ownership that was difficult to control. In addition, the shrublands were unmanaged lands that became open access or easy to use for various activities by the community, including land clearing and burning.

\section{Spatial hotspot distribution based on biophysical factors and accessibility}

Distribution of fire activities based on biophysical factors and accessibility is shown in Figures 3-8. The highest density of hotspot also occurs in areas with land cover in the form of swamp shrubs and open land (Figure 3). The hotspot density increases with the decreasing distance from rivers and canals including the canal as shown in Figure 4. Closer to the river, denser hotspots are detected. Hotspot density also increases as the distance from roads decreases (Figure 5). The highest density of hotspots is found in areas $1 \mathrm{~km}$ away from the road. Hotspot density is also related to the distance from villages. The highest density of hotspots is at a distance of $3-5 \mathrm{~km}$ from the center of the village (Figure 6). Figure 7 shows the density of hotspots by types of land. The highest value of hotspot density occurred in $2002\left(0.4\right.$ hotspots $\left./ \mathrm{km}^{2}\right)$ mostly found in peatland in the exPLG area that burns annually. Based on Figure 8, the highest density of hotspots occurs mostly on medium peatland $(100-200 \mathrm{~cm})$, very deep $(400-800 \mathrm{~cm})$ or extremely deep $(800-1200 \mathrm{~cm})$.

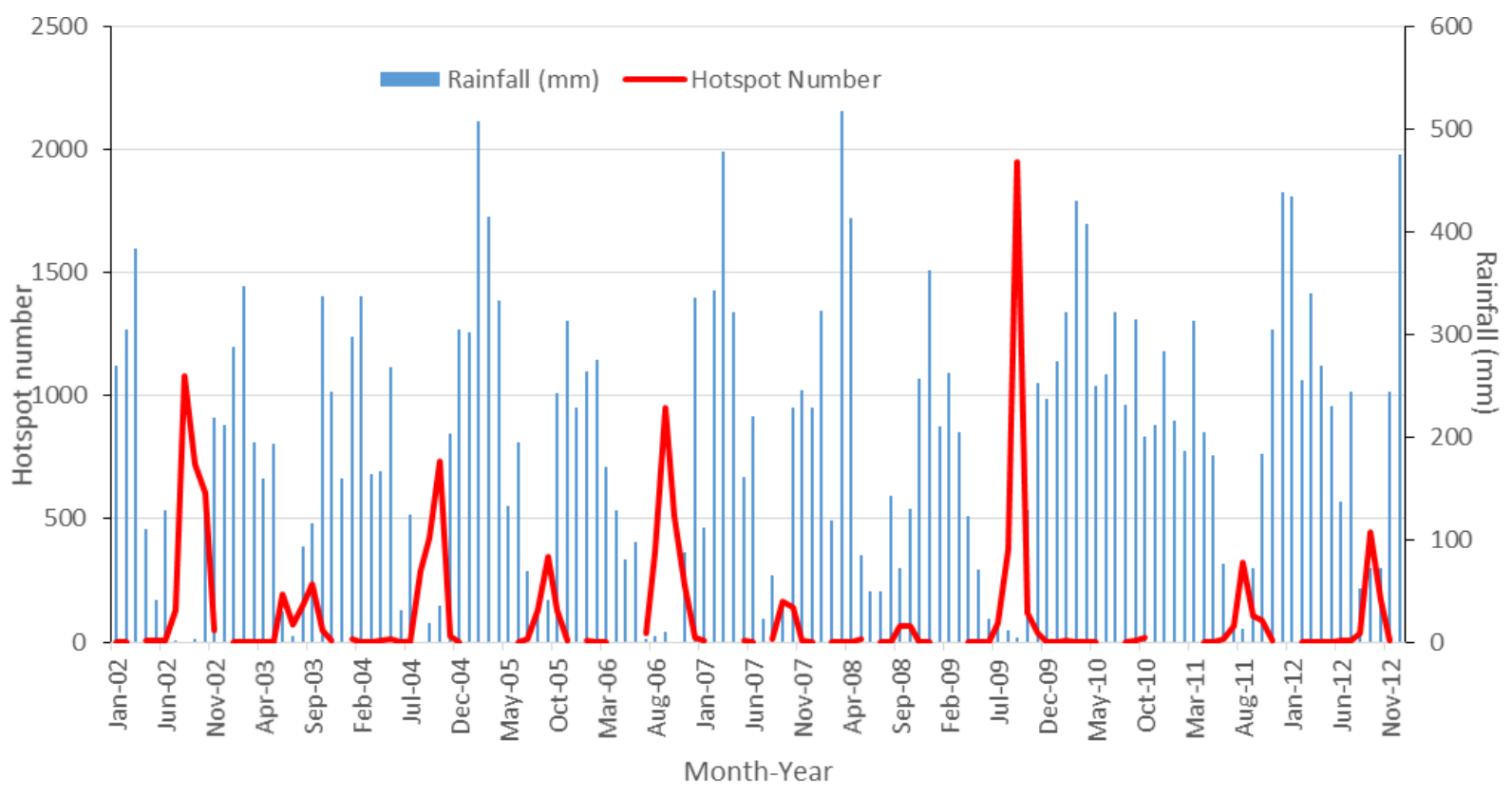

Figure 2. Relationship between monthly rainfall and monthly hotspot number in Kapuas District, Central Kalimantan, Indonesia 20012011 (Data were taken from rainfall data from Agriculture and Food Security Office of Kapuas District (2012) and hotspot fromTerra/Aqua MODIS) 
Table 1. Causes of Forest and land fire in Kapuas District, Central Kalimantan, Indonesia

\begin{tabular}{|c|c|c|c|c|c|c|c|c|c|c|c|c|}
\hline \multirow{2}{*}{ Causes/sources of fire } & \multicolumn{11}{|c|}{ Sub-district } & \multirow[b]{2}{*}{ Total } \\
\hline & Bas & Man & Kku & Sel & Kmu & Tim & Kte & Lta & Kti & Dad & Kba & \\
\hline Land clearing for dry agricultural land & 1 & 0 & 0 & 0 & 1 & 0 & 1 & 1 & 1 & 0 & 0 & 4 \\
\hline Land clearing for paddy fields & 0 & 0 & 1 & 0 & 0 & 0 & 0 & 0 & 1 & 0 & 0 & 2 \\
\hline Wildfire from shrub/grassland unmanaged land & 1 & 1 & 0 & 1 & 0 & 1 & 0 & 0 & 0 & 1 & 0 & 5 \\
\hline Burning galam forest (secondary swamp forest) for farmland & 1 & 0 & 0 & 1 & 1 & 0 & 0 & 0 & 1 & 1 & 0 & 5 \\
\hline Land tenure claim & 0 & 0 & 0 & 0 & 0 & 0 & 1 & 0 & 0 & 0 & 0 & 1 \\
\hline Land clearing around the gold mine area & 0 & 0 & 0 & 0 & 0 & 0 & 1 & 0 & 0 & 0 & 0 & 1 \\
\hline Land clearing to dispose of pests & 0 & 1 & 0 & 0 & 0 & 0 & 0 & 0 & 0 & 1 & 0 & 2 \\
\hline Wildfire from hunting activities & 1 & 1 & 0 & 0 & 0 & 0 & 0 & 0 & 0 & 1 & 0 & 3 \\
\hline Wildfire from fishing activities & 0 & 1 & 0 & 0 & 0 & 0 & 0 & 0 & 0 & 0 & 0 & 1 \\
\hline Wildfire from smoking activity & 0 & 1 & 0 & 0 & 0 & 1 & 0 & 0 & 1 & 1 & 0 & 4 \\
\hline Logging activities in the forest & 0 & 1 & 0 & 0 & 0 & 0 & 0 & 0 & 0 & 0 & 0 & 1 \\
\hline Conversion from secondary forest to plantation & 0 & 1 & 0 & 0 & 0 & 0 & 0 & 0 & 0 & 0 & 0 & 1 \\
\hline
\end{tabular}

Note: 1: present, 0: absent, Bas: Basarang, Man: Mantangai, Kku: Kapuas Kuala, Sel: Selat, Kmu: Kapuas Murung, Tim: Timpah, Kte: Kapuas Tengah, Lta: Lapak Taliwang, Kti: Kapuas Timur, Dad: Dadahup, Kba: Kapuas Barat

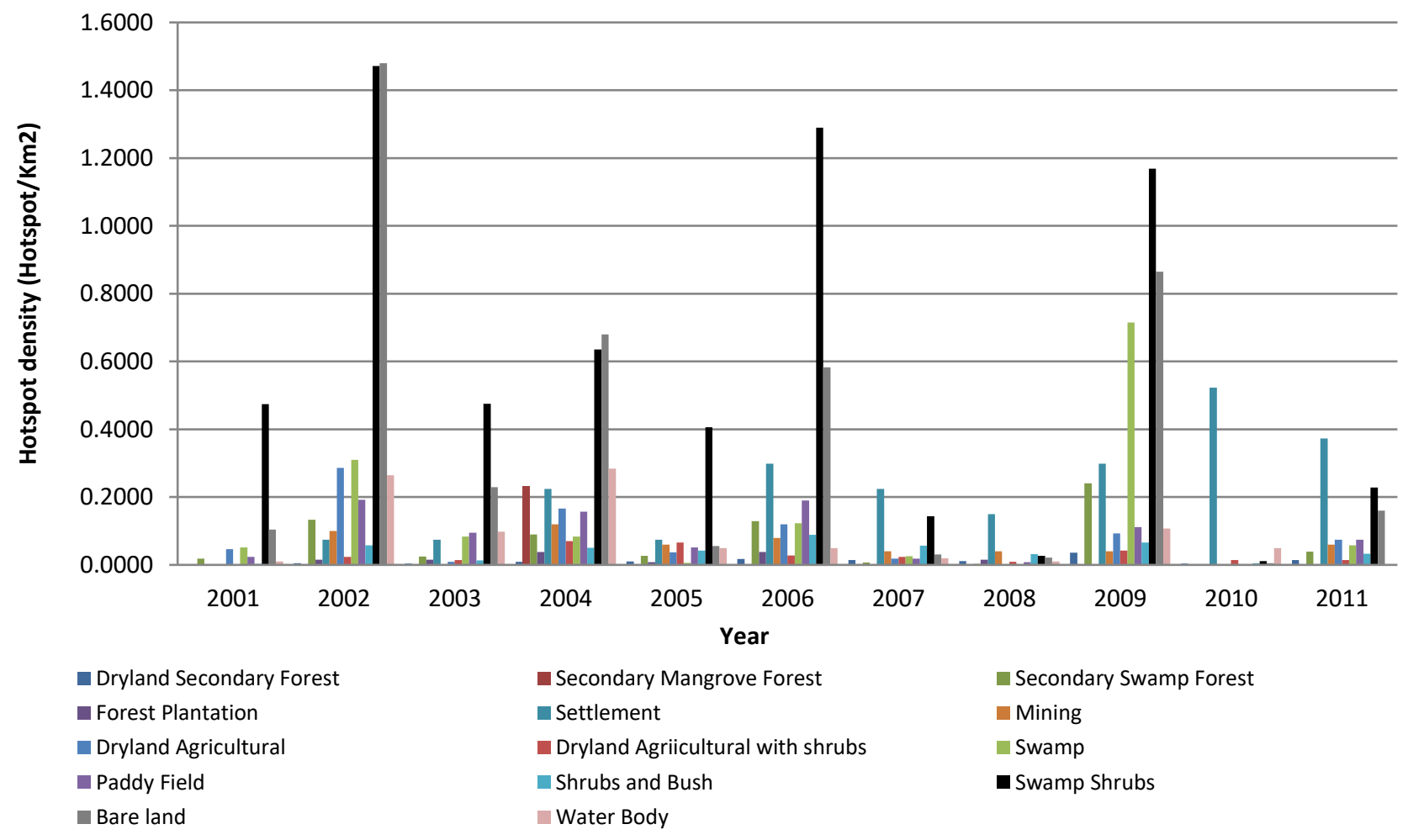

Figure 3. Hotspot density based on land cover in Kapuas District, Central Kalimantan, Indonesia, 2001-2011

\section{Discussion}

The hotspot distribution as shown in Figure 2 shows that a large number of fire activities occurred in El Nino year, namely 2002, 2006 and 2009. Langner and Siegert (2009) noted that the recurrent fires of 2002, 2006 and 2009 occurred in the ex-PLG area increasing hotspots in Kapuas District.

Generally, hotspots increase when rainfall decreases. Based on Figure 2, hotspots increase drastically in JuneAugust almost every year. Study by Tata et al. (2018) also found a similar pattern in Pelalawan District of Riau Province that the majority of hotspots usually occurred in June to August. Rainfall is very influential on the water content of fuel, especially on peatlands. As rainfall increases, peatlands will store large amounts of water so the water content of the fuel increases and they are difficult to burn. When the rainfall decreases, the water content of the peat decreases. Peat with low moisture is very susceptible to burning. Taufik et a.l (2011) and Syaufina et al. (2004) found that rainfall greatly affected the dynamics of groundwater and groundwater level. Both fluctuations are strongly influenced by the dynamics of rainfall soaking the soil. In low rainfall season, water level falls on critical thresholds that cause peatlands highly flammable (Wosten et al. 2008). 


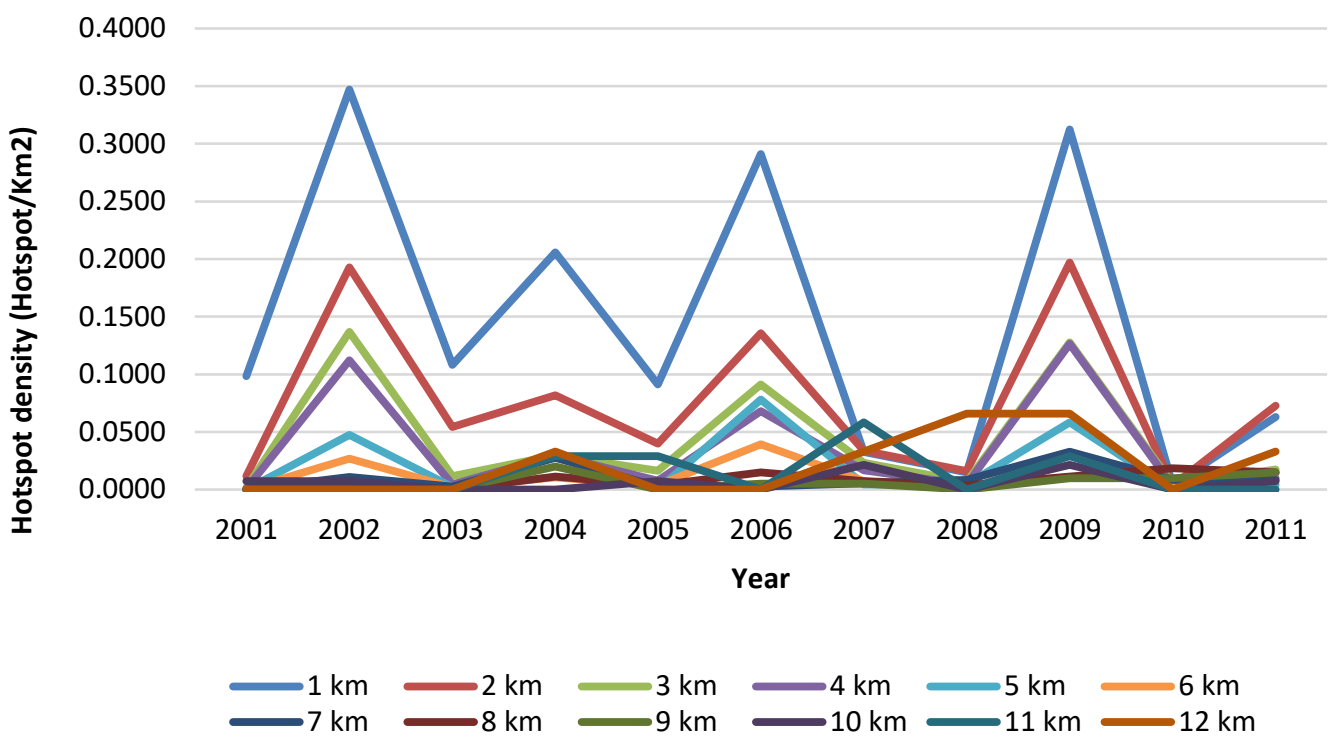

Figure 4. Hotspot density based on distance from river and canal in Kapuas District, Central Kalimantan, Indonesia, 2001-2011

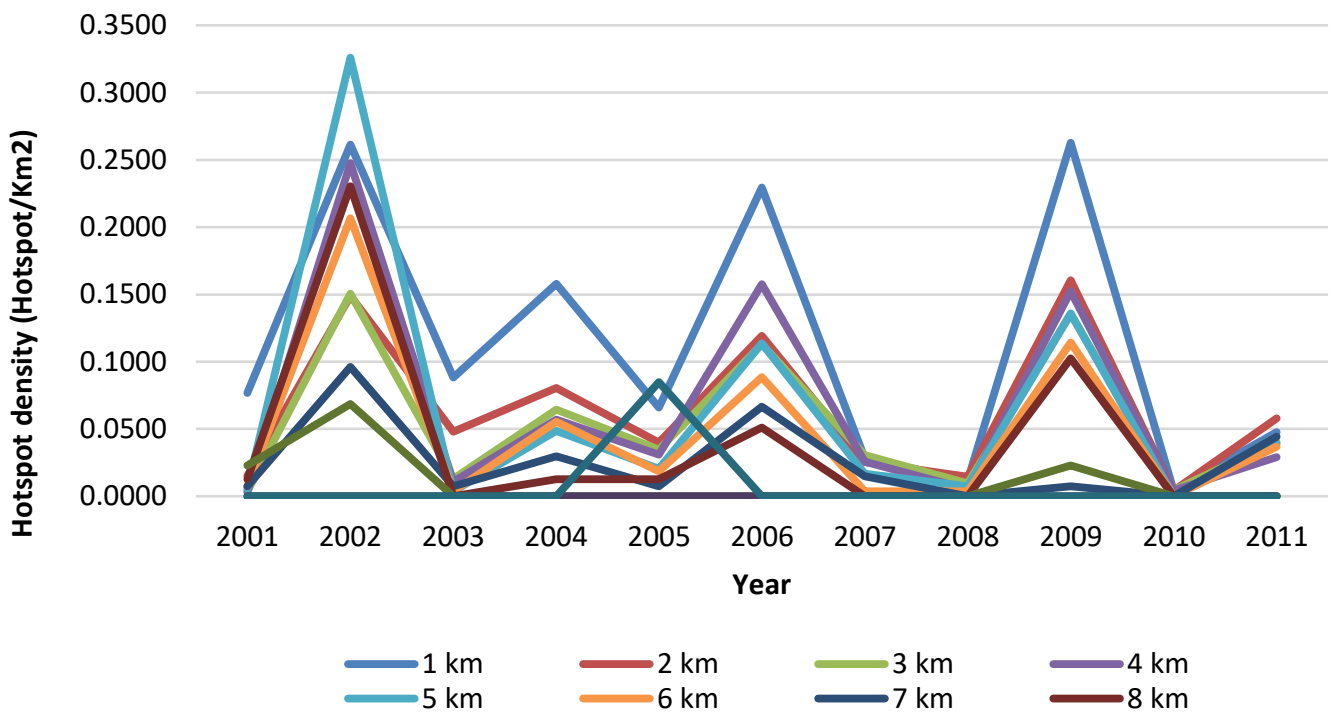

Figure 5. Hotspot density based on distance from road in Kapuas District, Central Kalimantan, Indonesia, 2001-2011

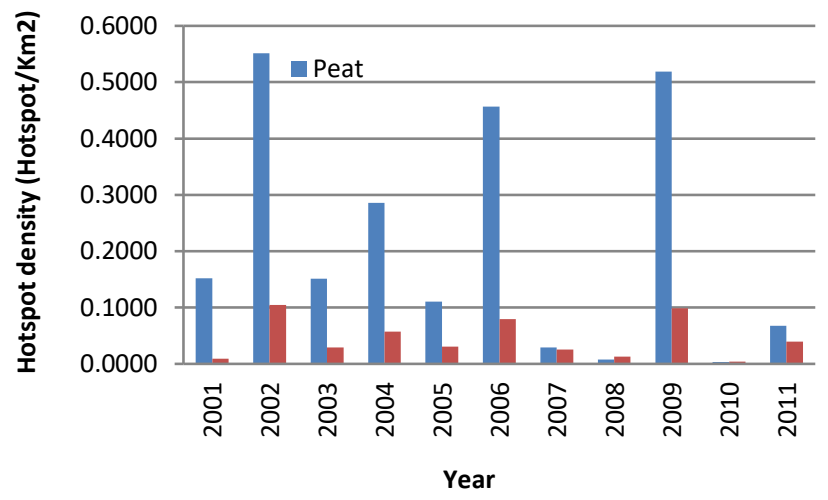

Figure 7. Hotspot density on peatland and non-peatland center in Kapuas District, Central Kalimantan, Indonesia, 2001-2011
The highest number of hotspots occurred in 2002, 2006 and 2009. There was a steep increase in the number of hotspots in months where rainfall was low (rainfall below $150 \mathrm{~mm}$ ). The highest number of hotspots per month occurred in August-October with at least 100 hotspots. Increased hotspots were sharply related to community activities associated with land clearing in the dry season. Study of Someshwar et al. (2010) mentioned that farmers and smallholders in Central Kalimantan cleared the land during that time (June-September), because the biomass dried faster. They clean up the land by burning so in that time period more fires occurred. 


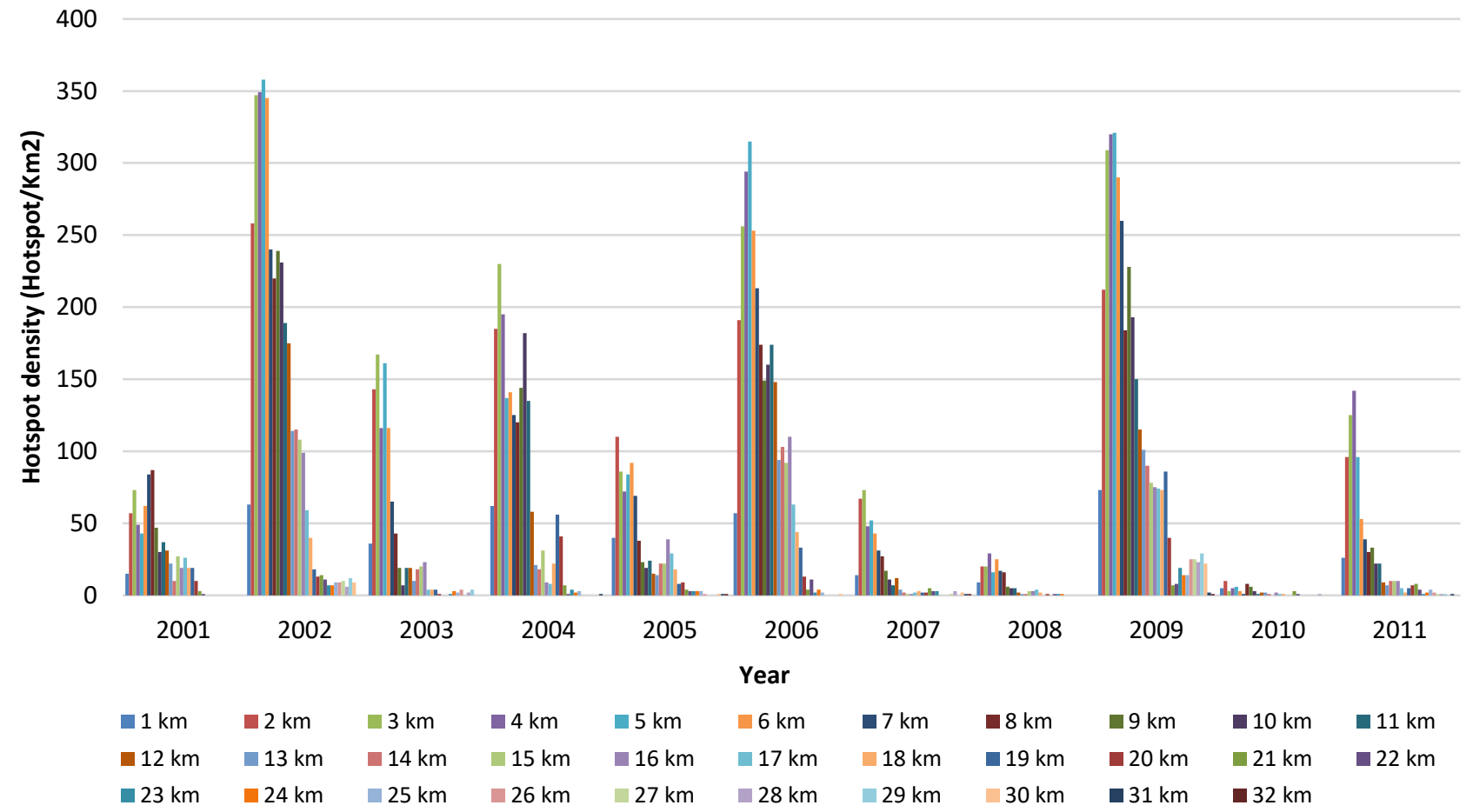

Figure 6. Hotspot density based on distance from village center in Kapuas District, Central Kalimantan, Indonesia, 2001-2011

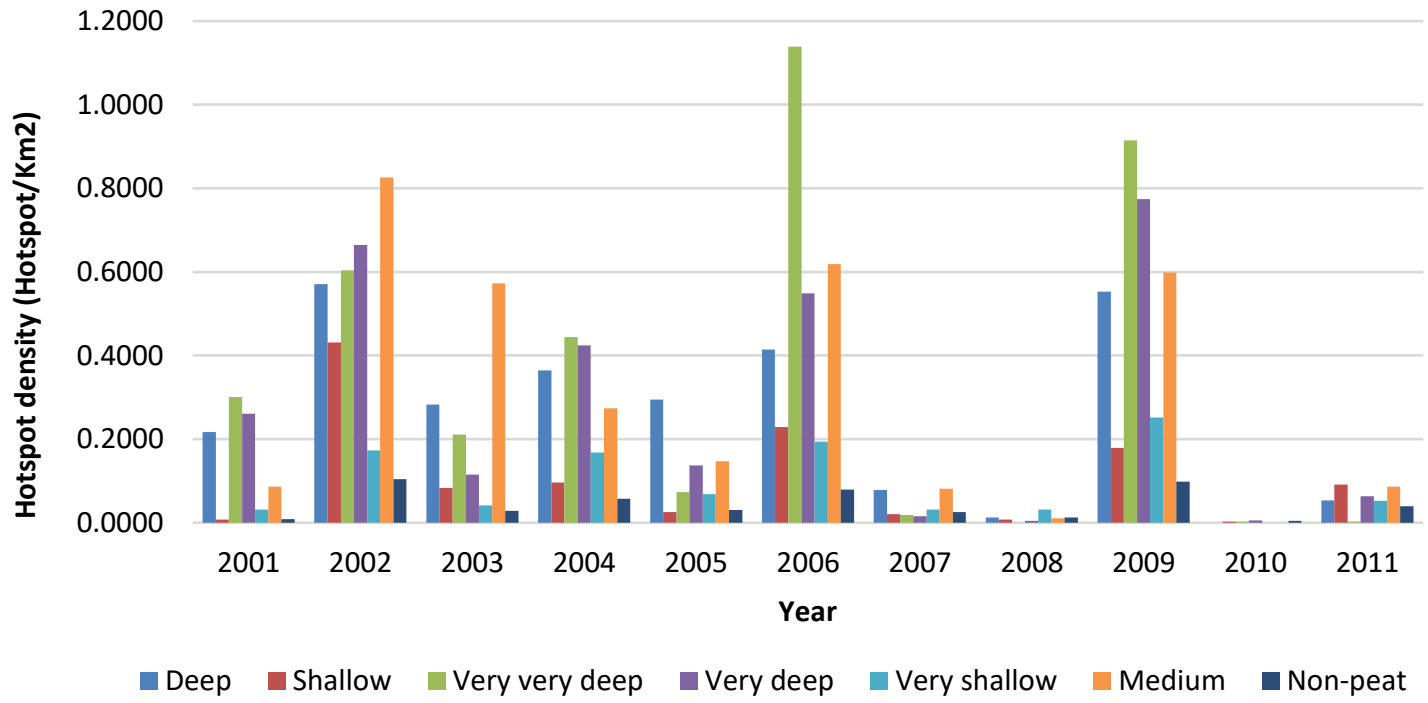

Figure 8. Hotspot density based on peat depth in Kapuas District, Central Kalimantan, Indonesia, 2001-2011

According to a study by Thoha et al. (2014), unmanaged land such as shrublands and grassland generally become source of fire in Kapuas District. Thoha et al. (2018) also found that unmanaged land almost burns every dry season. Other causes of fire are clearing of land for dry agricultural land, for paddy fields, for having land tenure,clearing of areas around the gold mine, clearing land to dispose of pests, wildfire from hunting, wildfire from fishing activities, wildfire from smoking activities, timber harvesting and conversion from secondary forests to plantations. Research of Akbar et al. (2011) in the Kapuas peatland area found that the sources of land fires also came from farmers and fishers. In addition to the marsh bushes, galam forest was also a source of fire that many people mentioned. 
The highest density of hotspot also occurs in swamp shrubs and open land (Figure 3). Areas with the lowest density of hotspots are found in plantation forest and secondary mangrove forests. The swam bush is a vulnerable area because it provides abundant and flammable fuel loads. Open ground in the field was found in the form of grasslands of burned-out fields. Based on interviews with the community, fires often start from open land or abandoned land. Open land becomes prone to be burned by communities such as hunting and fishing or burning due to negligence in smoking activity.

The hotspot density increases as the distance from rivers and canals decrease as shown in Figure 4. Closer to the river, denser hotspots are detected. The density of the hotspots will decrease and no hotspot is found in areas over $6 \mathrm{~km}$ from the river. This is related to the activities of people who utilize rivers and canals, such as picking and transporting timber, hunting, fishing, and farming. According to Hecker (2005) and Hooijer et al. (2008), more than $4000 \mathrm{~km}$ of canals have been built in the ex-peat land area of the Ex-PLG which provides access to the peatlands that allows a lot of community activities to take place. Soewarso's (2003) study on peat swamp forest on the Sugihan River also found that the closer the river and canal, the higher the chances of a fire was.

Hotspot density also increases with the decreasing distance to roads (Figure 5). The highest density of hotspots is found in areas $1 \mathrm{~km}$ away from the road. Roads provide access to communities and corporations to conduct a variety of activities that cause the land vulnerable to cultivation. Many people clear the land by burning, generally close to the road. Activities that cause burning land are smoking activity and clearing land for getting land tenure. Analysis of Boer et al. (2007) also showed that significant portions of fires in Central Kalimantan occur close to the road network, which can also predict the important causes of fire.

The highest density of hotspots is at a distance of 3-5 $\mathrm{km}$ from the center of the village (Figure 6). In the year when the incident of high fires occurred in 2002, 2006 and 2009 , the highest density was found in the area $6-10 \mathrm{~km}$ away from the village center. In areas which are very close to the villages, people tend to take good care of their land so they are relatively safe from fires. In the center of the village, there are many community settlements and public facilities, so it generally gets intensive supervision and care.

Figure 7 shows the density of hotspots by types of land. The highest value of hotspot density which occurred in $2002\left(0.4\right.$ hotspots $\left./ \mathrm{km}^{2}\right)$ was mostly found in peatland in the ex-PLG area that burns annually. Burning peat is difficult to extinguish and the flames can creep beneath the surface so land fires can spread out of control. Dry peat with very low moisture levels due to drought and irreversible drying in the dry season becomes a combustible fuel, being a detected hotspot area in high density. According to Agus and Subiksa (2008), the dried peat cannot absorb water anymore if it is dampened so it is easily burned.
Based on Figure 8, the highest density of hotspots occurs mostly on medium peatland $(100-200 \mathrm{~cm})$, very deep $(400-800 \mathrm{~cm})$ or extremely deep $(800-1200 \mathrm{~cm})$. The lowest hotspot density was found in non-peat areas. In the year with the highest density of the hotspot, the depth of the peat area shifted from a medium depth to extremely deep. In 2002 the highest density of hotspots was found in medium peatland, but in 2006 and 2009, it shifted to an extremely deep peatland. Langner and Siegert's research (2009) found that repeated fires occurred during 15 years of peatland drainage in 2002, 2004, 2006 and 2009 in peatland at ex-PLG sites. Peatland has a type of ground fire.

We conclude that a strong indication of the forest and land fires location in Kapuas district is indicated by Terra/Aqua MODIS satellites with a confidence value of more than $50 \%$. The number of hotspots is inversely proportional to rainfall. According to the time, AugustOctober is the time of hotspot in Kapuas District. The high number of hotspots does not always indicate the fires occurred in regions of Kapuas District. Hotspot density as an indication of fire activity is determined by the presence of peatlands, land cover, accessibility, and human activities. Areas with the densest hotspots are generally distributed on peat soil sites with marshland bush cover, close to the river, close to the road, some distance from humans and on farmland and plantation cultivation fields.

\section{ACKNOWLEDGEMENTS}

The research was funded by Columbia University, USA and Bogor Agricultural University, Indonesia Partnership to Build Capacity for Adaptation to Climate Risks In Indonesia, USAID Grant No.AID-497-A-11-00011. Acknowledgments are given to Manggala Agni Operation Area II Kapuas of Natural Resources Conservation Center (BKSDA) Central Kalimantan for the support and assistance given to the researcher during the data collection process. The researcher also thanked the editorial staff and peer reviewer who have provided valuable corrections and comments on the manuscript.

\section{REFERENCES}

Agus F, Subiksa IGM. 2008. Lahan Gambut: Potensi untuk pertanian dan aspek lingkungan. Balai Penelitian Tanah dan World Agroforestry Centre (ICRAF), Bogor. [Indonesian]

Akbar A, Sumardi R, Purwanto H, Sabarudin MS. 2011. Studi sumber penyebab terjadinya kebakaran dan respon masyarakat dalam rangka pengendalian kebakaran hutan gambut di Areal Mawas, Kalimantan Tengah. Jurnal Penelitian Hutan Tanaman 8: 287-300. [Indonesian]

Badan Perncanaan Pembangunan Daerah [Bappeda] Kabupaten Kapuas. 2012. Peta Batas Administrasi Kabupaten Kapuas. Badan Perncanaan Pembangunan Kabupaten Kapuas. Kuala Kapuas [Indonesian]

Boer R, Kolopaking L, Bagja D, Dasanto DD. 2007. Early Warning Systems in Indonesia for flood, forest fire, volcano eruption and tsunami. Final Report. GTZ, Jakarta.

Ceccato P, Jaya INS, Qian JH, Tippet MK, Robertson AW, Someshwar S. 2010. Early Warning and Response to Fires in Kalimantan, Indonesia. IRI Technical Report 10-14, International Research Institute for Climate and Society, Palisades, NY.

Cochrane MA. 2003. Fire science for rainforests. Nature 421: 913-919. 
Agriculture and Food Security Agency of Kapuas District. 2012. Data dan Informasi Cuaca Kabupaten Kapuas 2002-2012. Dinas Pertanian, Hortikultura dan Tanaman Pangan Kabupaten Kapuas, Kapuas [Indonesian]

Plantation Forestry Office of Kapuas District [Dinas Perkebunan dan Kehutanan Kabupaten Kapuas]. 2013. Paparan Pengendalian Kebakaran Hutan dan Lahan di Kabupaten Kapuas. Workshop "Climate Analytic and Forecasting for Risk Management" Bogor , 23 -24 September 2013.

Fire Information for Resource Management System [FIRMS]. 2012 Archive Download. https://firms.modaps.eosdis.nasa.gov/download

Hecker JH. 2005. Promoting Environmental Security and Poverty Alleviation in the Peat Swamps of Central Kalimantan, Indonesia Commissioned by the Institute for Environmental Security, The Netherlands.

Hooijer A, Van der Vat M, Prinsen G, Vernimmen R, Brinkman J J, Zijl F. 2008. Hydrology of the EMRP Area-Water Management Implications for the Peatlands. Technical Report Number 2, Master Plan for the Rehabilitation and Revitalization of the Ex-Mega Rice Project Area in Central Kalimantan. Euroconsult Mott MacDonald and Deltares and Delft Hydraulics, Nederlands.

Jaya INS, R Boer, Samsuri, Fathurakhman. 2008. Development of wildfire vulnerability index in Central Kalimantan. Research Report. CARE Indonesia, Bogor.

Ministry of Forestry. 2011b. Peta dan Data Kebakaran Lahan di Daerah Operasi II Kapuas. Balai Konservasi Sumberdaya Alam Kalimantan Tengah Daerah Operasi II Kapuas. Kapuas [Indonesian].

Ministry of Forestry. 2011a. Laporan Patroli dan Pemantauan Titik Panas di Wilayah Manggala Agni Daerah Operasi II Kapuas. Balai Konservasi Sumberdaya Alam Kalimantan Tengah. Kapuas [Indonesian]

Langner A, Siegert F. 2009. Spatiotemporal fire occurrence in Borneo over a period of 10 years. Glob Ch Biol 15: 48-62.
Soewarso. 2003. Penyusunan Pencegahan Kebakaran Hutan Rawa Gambut dengan Menggunakan Model Prediksi. [Disertasi]. Sekolah Pascasarjana, Institut Pertanian Bogor, Bogor. [Indonesian]

Someshwar S, Boer R, Conrad E. 2010. World Resources Report Case Study. Managing Peatland Fire Risk in Central Kalimantan, Indonesia. World Resources Report, Washington DC.

Syaufina L, Nuruddin AA, Basharuddin J, See LF, Yusof MRM. 2004. The effects of climatic variations on peat swamp forest condition and peat combustibility. Jurnal Manajemen Hutan Tropika 10 (1): 1-14

Taufik M, Setiawan BI, Prasetyo LB, Pandjaitan NH, Soewarso. 2011. Pengembangan Indeks Bahaya Kebakaran Di HTI SBAWI Sumatra Selatan. Jurnal Penelitian Hutan Tanaman 8 (4): 215-223. [Indonesian]

Tata HL, Naendra BH, Mawazin. 2018. Forest and land fires in Pelalawan District, Riau, Indonesia: Drivers, pressures, impacts and responses. Biodiversitas 19 (2) : 494-501

Thoha AS, Saharjo BH, Boer R, Ardiansyah M. 2014. Spatiotemporal distribution of peatland fires in Kapuas District, Central Kalimantan Province, Indonesia Agric For Fisher 3 (3): 163-170.

Thoha AS, Saharjo BH, Boer R, Ardiansyah M. 2017. Forest and land fires hazard level modeling: case study of Kapuas, Central Kalimantan. In: Djalante R, Garschagen M, Thomalla F, Shaw R. (eds) Disaster Risk Reduction in Indonesia. Disaster Risk Reduction (Methods, Approaches, and Practices). Springer, Cham.

Thoha AS, Saharjo BH, Boer R, Ardiansyah M. 2018. Strengthening community participation in reducing GHG emission from forest and peatland fire. IOP Conf. Series: Earth and Environmental Science 122 (2018) 012076. DOI:10.1088/1755-1315/122/1/012076.

Wetland International Indonesia Program [WIIP]. 2007. Pengelolaan Lahan Gambut Berbasis Masyarakat di Indonesia. Wetland International Indonesia Programme, Bogor. [Indonesian]

Wosten JHM, Clymans E, Page SE, Riley JO, Limin SH. 2008. Peat-water interrelationships in a tropical peatland ecosystem in Southeast Asia. Catena 73: 212-224. 